\title{
Kistrin, an Integrin Antagonist, Blocks Endocytosis of Fibrinogen into Guinea Pig Megakaryocyte and Platelet $\alpha$-Granules
}

\author{
Prem Handagama, * Dorothy F. Bainton," Yvonne Jacques," Marion T. Conn, ${ }^{\star}$ Robert A. Lazarus," and Marc A. Shuman” \\ Departments of ${ }^{*}$ Pathology and ${ }^{\ddagger}$ Medicine, University of California, San Francisco, California $94143-0506$ and \\ ${ }^{8}$ Department of Protein Engineering, Genentech, Inc., South San Francisco, California 94080
}

\begin{abstract}
Recent data indicate that megakaryocyte/platelet $\alpha$-granule fibrinogen is endocytosed from plasma. Because fibrinogen is the major platelet protein present in high concentrations in $\alpha$-granules, fibrinogen uptake into $\alpha$-granules may occur via specific receptors. In that cells of the megakaryocyte/platelet lineage contain two integrins $-\alpha_{\mathrm{mb}} \beta_{3}$ (GP IIb-IIIa) and the vitronectin receptor $\left(\alpha^{\top} \beta_{3}\right)$-that can bind fibrinogen, one or both of these receptors may mediate the endocytic uptake of fibrinogen. To test this hypothesis, we examined the effect of Kistrin, an RGD-containing protein purified from the venom of Agkistrodon rhodostoma that inhibits fibrinogen binding to human platelet receptors, on endocytosis of fibrinogen by megakaryocytes and platelets. Continuous intravenous infusion of kistrin into guinea pigs $(200 \mu \mathrm{g} / \mathrm{h})$ over a $24-\mathrm{h}$ period inhibited collagen-induced platelet aggregation. When biotinylated fibrinogen was injected intravenously into animals receiving Kistrin, megakaryocytes failed to endocytose the labeled fibrinogen. Endocytosis of fibrinogen into platelets was also inhibited in these animals. In contrast, platelets and megakaryocytes obtained from shaminfused control animals contained the injected biotinylated fibrinogen. We conclude that, in addition to the well-known extracellular function of cell adhesion, integrins can also act as receptors that mediate endocytosis of exogenous proteins and incorporate them into regulated secretory granules. (J. Clin. Invest. 1993. 91:193-200.) Key words: disintegrin • immunocytochemistry • platelet receptors • receptor-mediated endocytosis • secretory granules
\end{abstract}

\section{Introduction}

Investigations using the sensitive polymerase chain reaction have shown that, whereas fibrinogen is a major platelet $\alpha$-granule protein, megakaryocytes, the bone marrow precursor cells from which platelets are derived, do not contain the specific mRNA for fibrinogen (1-3). Thus, megakaryocytes do not synthesize the fibrinogen present in $\alpha$-granules, but rather, acquire these proteins by endocytosis $(4,5)$. Therefore, the platelet $\alpha$ granule appears to be a unique type of secretory granule, whose contents originate both by endogenous synthesis (i.e., platelet

Address reprint requests to Dr. Handagama, Box 0506/HSW-501, Pathology Department, University of California, San Francisco, CA 94143-0506.

Received for publication 13 February 1992 and in revised form 17 August 1992.

\section{J. Clin. Invest.}

(c) The American Society for Clinical Investigation, Inc.

0021-9738/93/01/0193/08 \$2.00

Volume 91, January 1993, 193-200 factor $\left.4[\mathrm{PF}-4]^{1}\right)$ and endocytosis of circulating plasma proteins (fibrinogen, immunoglobulin $G$, and albumin) $(1,4)$. Because fibrinogen is present in higher concentrations relative to the other endocytosed plasma proteins such as albumin and IgG, it has been postulated that endocytosis of fibrinogen by megakaryocytes and platelets may be receptor mediated $(4,6,7)$. The major fibrinogen receptor on platelets, $\alpha_{\mathrm{Inb}} \beta_{3}$, is present in large numbers ( 50,000 receptors per platelet), and although cell type specific, belongs to a supergene family of cell surface receptors known as integrins (8-10). In addition to $\alpha_{\mathrm{IIb}} \beta_{3}$, platelets (and presumably megakaryocytes) also contain several other integrins, including vitronectin $\left(\alpha^{\mathbf{v}} \beta_{3}\right)$, collagen $\left(\alpha_{2} \beta 1\right)$, fibronectin ( $\alpha 5 \beta 1$ ), and laminin (VLA-6) receptors. One of these, $\alpha^{\mathrm{v}} \beta_{3}$, also binds fibrinogen $(11,12)$, but is present in very low numbers ( $\sim$ 50-100 per platelet) (13).

We hypothesized that, if $\alpha_{\mathrm{Im}} \beta_{3}$ and/or $\alpha^{\mathrm{v}} \beta_{3}$ are the receptor(s) that mediate fibrinogen uptake, an antagonist of these receptors, such as kistrin, might inhibit fibrinogen endocytosis. Kistrin $\left(M_{\mathrm{r}} 7,318\right)$ belongs to a group of integrin inhibitory proteins isolated from viper venoms, known as disintegrins, that contains the arg-gly-asp (RGD) sequence, and binds with high affinity to platelet $\alpha_{\mathrm{IIb}} \beta_{3}(14,15)$. Kistrin directly inhibits the interaction of purified platelet $\alpha_{\mathrm{IIb}} \beta_{3}$ with immobilized fibrinogen $\sim 100$ times more effectively than does gly-arg-glyasp-ser (14). Furthermore, Kistrin injected into animals reversibly inhibits platelet aggregation in vivo without induction of thrombocytopenia (14). Kistrin also binds to $\alpha^{\mathrm{v}} \beta_{3}$ (16).

The question that we have asked is whether an antagonist to platelet fibrinogen receptors $\alpha_{\mathrm{IIb}} \beta_{3}$ and $\alpha^{\mathrm{v}} \beta_{3}$ can block megakaryocyte and platelet uptake of biotinylated fibrinogen in vivo. In the present study, we tested this hypothesis by infusing kistrin into guinea pigs and determining the extent of uptake of biotinylated fibrinogen into megakaryocytes and platelets. Our results showed that kistrin blocked endocytic uptake of fibrinogen into these cells, suggesting that, indeed, the receptor that mediates endocytosis of fibrinogen is an integrin.

\section{Materials}

\section{Methods}

Proteins and reagents. Human fibrinogen (grade L, KabiVitrum, Stockholm, Sweden) was used in all experiments. Kistrin was prepared as previously described (14). The antibodies used were rabbit antiguinea pig albumin (Cappel, Organon Teknika Corp., Rockville, MD), rabbit anti-human von Willebrand factor (vWf; Dako Corp., Carpinteria, CA), rabbit anti-biotin (Enzo Biochem Inc., New York), and anti-human PF-4 (a gift from Dr. Shirley Levine, San Antonio, TX). These antibodies, made against human proteins, cross-react with their guinea pig counterparts. The biotinylated goat anti-rabbit IgG secondary antibody was from Vector Labs Inc., Burlingame, CA, and the

1. Abbreviation used in this paper: PF-4, platelet factor 4. 
1-nm gold-conjugated goat anti-rabbit IgG was from Amersham Corp., Arlington Heights, IL. The streptavidin-conjugated peroxidase and biotinylated peroxidase were from Zymed Labs., San Francisco. The blocking reagents for endogenous tissue biotin consisting of avidin-D and biotin were from Vector Labs.

Biotinylation of fibrinogen. Purified fibrinogen was biotinylated according to a previously described method (4). This biotinylated fibrinogen migrated as the intact protein on Western immunoblots, and no biotinylated degradation products were detected.

Biotinylation of kistrin. $5.0 \mathrm{mg}$ of kistrin, $2.5 \mathrm{mg} / \mathrm{ml}$ in $0.15 \mathrm{M}$ $\mathrm{NaCl} / 0.01 \mathrm{M} \mathrm{NaPO} 4, \mathrm{pH} 7.4$ was incubated with biotinyl-є-amino-caproic acid $\mathrm{N}$-hydroxysuccinimide ester at a final concentration of 50 $\mu \mathrm{g} / \mathrm{ml}$ at $0^{\circ} \mathrm{C}$ for $3 \mathrm{~h}$. The kistrin was then dialyzed extensively against $0.15 \mathrm{M} \mathrm{NaCl} / 0.01 \mathrm{M} \mathrm{NaPO}_{4}(\mathrm{pH} 7.4)$. Low molecular weight cutoff (mol wt 1,000)-dialysis tubing from Spectrum Medical Industries Inc., Los Angeles, CA, was used.

Determining the endocytic receptor blocking effect of kistrin in vivo. 10 male Hartley guinea pigs, each weighing $450-500 \mathrm{~g}$, were used in the experiments. Because kistrin appears to have a short in vivo half-life (14) it was administered by slow, continuous, intravenous infusion in order to maintain a sustained plasma kistrin level (thereby maintaining a continuous blockade of the receptors). All substances were administered to guinea pigs via an indwelling jugular catheter. Continuous infusions were carried out using a compact infusion pump. In experiments designed to determine the receptor-blocking effects of kistrin, animals were given $200 \mu \mathrm{g}$ of kistrin over $1 \mathrm{~h}$ by continuous intravenous infusion followed by a $250-\mathrm{mg}$ bolus of biotinylated fibrinogen. The infusion of kistrin at $200 \mu \mathrm{g} / \mathrm{h}$ was then continued for $24 \mathrm{~h}$. In control animals, in addition to biotinylated fibrinogen, saline was administered in similar volumes in place of kistrin. Animals were killed $24 \mathrm{~h}$ later, and the bone marrow and blood platelets were processed for immunohistochemical detection of biotinylated fibrinogen.

Determining the fate of kistrin molecules bound to megakaryocytes and platelets in vivo. A second group of experiments was carried out to determine the fate of kistrin that bound to megakaryocytes and platelets. In this experiment biotinylated kistrin was infused into guinea pigs over a 4-h period. Localization of biotinylated kistrin in megakaryocytes was carried out on plastic embedded bone marrow sections at the light microscopic level. Kistrin in platelets was localized at the ultrastructural level using frozen thin section electronmicroscopy as described below.

\section{Studies on megakaryocytes}

After the animals were killed, the bone marrow was perfusion-fixed

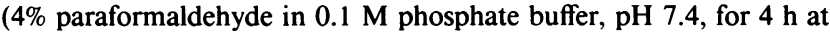
$4^{\circ} \mathrm{C}$ ), embedded in plastic (JB 4, Polysciences, Inc., Warrington, PA), and processed for immunohistochemistry as described previously (4).

Detection of biotinylated proteins in bone marrow. The biotinylated fibrinogen or kistrin was localized on plastic-embedded marrow sections by staining with streptavidin-peroxidase followed by biotinylated peroxidase.

Detection of other $\alpha$-granule proteins. Localization of albumin, vWf, and PF-4 in bone marrow megakaryocytes was carried out using immunohistochemical staining techniques previously described (4), except that the biotin sites in the tissue (injected biotinylated protein) were blocked using a biotin-blocking kit before applying the primary antibodies.

Control experiments. To determine the specificity of staining for biotin, bone marrow sections were preincubated with biotin-blocking reagents. Another control consisted of staining marrow from an untreated guinea pig for the presence of biotin. Controls for immunohistochemistry included the substitution of nonimmune rabbit serum for the primary antibody.

\section{Studies on platelets}

Platelet aggregometry. Platelet aggregation was performed using a whole-blood aggregometer (model 560 VS, Chrono-Log Corp., Havertown PA) with collagen as the agonist. Blood was collected by cardiac puncture into $3.8 \%$ sodium citrate. Efficacy of kistrin in the guinea pig was determined by the amount of kistrin needed to inhibit normal guinea pig platelet aggregation in vitro. Aggregation assays were done at the termination of the experiments on blood drawn from animals continuously infused with Kistrin or saline (control) for $24 \mathrm{~h}$.

Platelet counts. Platelet counts were done on samples obtained before kistrin treatment, 6 and $24 \mathrm{~h}$ after kistrin using a counter (Coulter Corp., Hialeah, FL).

Detection of biotinylated fibrinogen in platelets. Blood was collected from both kistrin-treated and control animals $24 \mathrm{~h}$ after infusion of biotinylated fibrinogen. Platelets were harvested, washed, and solubilized in $2.0 \%$ sodium dodecyl sulfate (SDS) as previously described (4). Solubilized platelets were electrophoresed in nonreduced SDS-5\% polyacrylamide gels at $100 \mathrm{~V}$. Proteins were transferred for $1 \mathrm{~h}$ at $100 \mathrm{~V}$ to $0.45-\mathrm{mm}$ nitrocellulose; blocked for $30 \mathrm{~min}$ with $5 \%$ gelatin, then incubated with avidin-horseradish peroxidase diluted 1:500 for $1 \mathrm{~h}$, and washed thrice with Tris-buffered saline (pH 7.4). The reaction was terminated with 4-chloronapthol and hydrogen peroxide.

Quantitation of detection threshold in Western blots. To determine the sensitivity of our Western blotting technique, a dilution series of biotinylated fibrinogen was electrophoresed in a SDS 5\% polyacrylamide gel, transferred to nitrocellulose, and stained with avidin-peroxidase as described above.

Detection of other $\alpha$-granule proteins in platelets. (a) Western blotting: the effect of kistrin on two other $\alpha$-granule proteins was determined using immunoblots. Rabbit antibodies against PF-4 and vWf (see above) were used for staining. (b) Radial immunodiffusion: quantitation of platelet $\alpha$-granule albumin was performed by radioimmunodiffusion, using a commercially available immunoplate for measuring low levels of albumin (NANORID Albumin LL, The Binding Site Inc., San Diego CA). Although the antibody used in the assay was against human albumin, it cross-reacted with the guinea pig counterpart. Washed guinea pig platelets were prepared as for Western blots. Platelets $\left(1 \times 10^{7}\right)$ were solubilized using $1 \%$ Triton X-100 in PBS, freeze thawing, and sonication for $15 \mathrm{~min}$. Three dilutions of purified guinea pig albumin (Sigma Chemical Co., St. Louis, MO) was used to obtain a standard curve, and results of the test sample were read off this graph.

Electronmicroscopic localization of kistrin in Platelets. The injected biotinylated kistrin was localized by electron microscopy on frozen thin sections to determine if kistrin molecules that bind to platelets were endocytosed. Platelets were fixed in $4 \%$ paraformaldehyde in 0.1 $\mathrm{M}$ phosphate buffer ( $\mathrm{pH} \mathrm{7.4)}$ for $2 \mathrm{~h}$ at $4^{\circ} \mathrm{C}$. Platelets were then infiltrated overnight with $2.3 \mathrm{M}$ sucrose, embedded in sucrose, frozen, and stored in liquid nitrogen till sections were cut. Biotinylated kistrin was localized using rabbit anti-biotin antibody and a 1-nm gold probe conjugated to goat anti-rabbit IgG. The small probe was then amplified using silver chloride to facilitate detection (17). Controls consisted of platelets from normal guinea pigs processed and stained identically.

\section{Results}

\section{Studies on Megakarycytes}

Effect of kistrin on endocytosis of fibrinogen by megakaryocytes. We previously showed that when biotinylated fibrinogen is administered to guinea pigs, it is endocytosed by bone marrow megakaryocytes and incorporated into $\alpha$-granules (4). Similarly, in the present study, the injected biotinylated fibrinogen was endocytosed by bone marrow megakaryocytes in control animals (Fig. $1 a$ ). In addition, the presence of biotinylated fibrinogen in the bone marrow vasculature suggested that it was still circulating at the time of death (Fig. $1 a$ ). In contrast, when biotinylated fibrinogen was injected into animals given kistrin, there was a marked diminution to complete absence of staining in bone marrow megakaryocytes (Fig. $1 b$ ). Quantitative analysis of these data is presented in Table I. Although megakaryocytes lacked biotinylated fibrinogen, marrow sinu- 

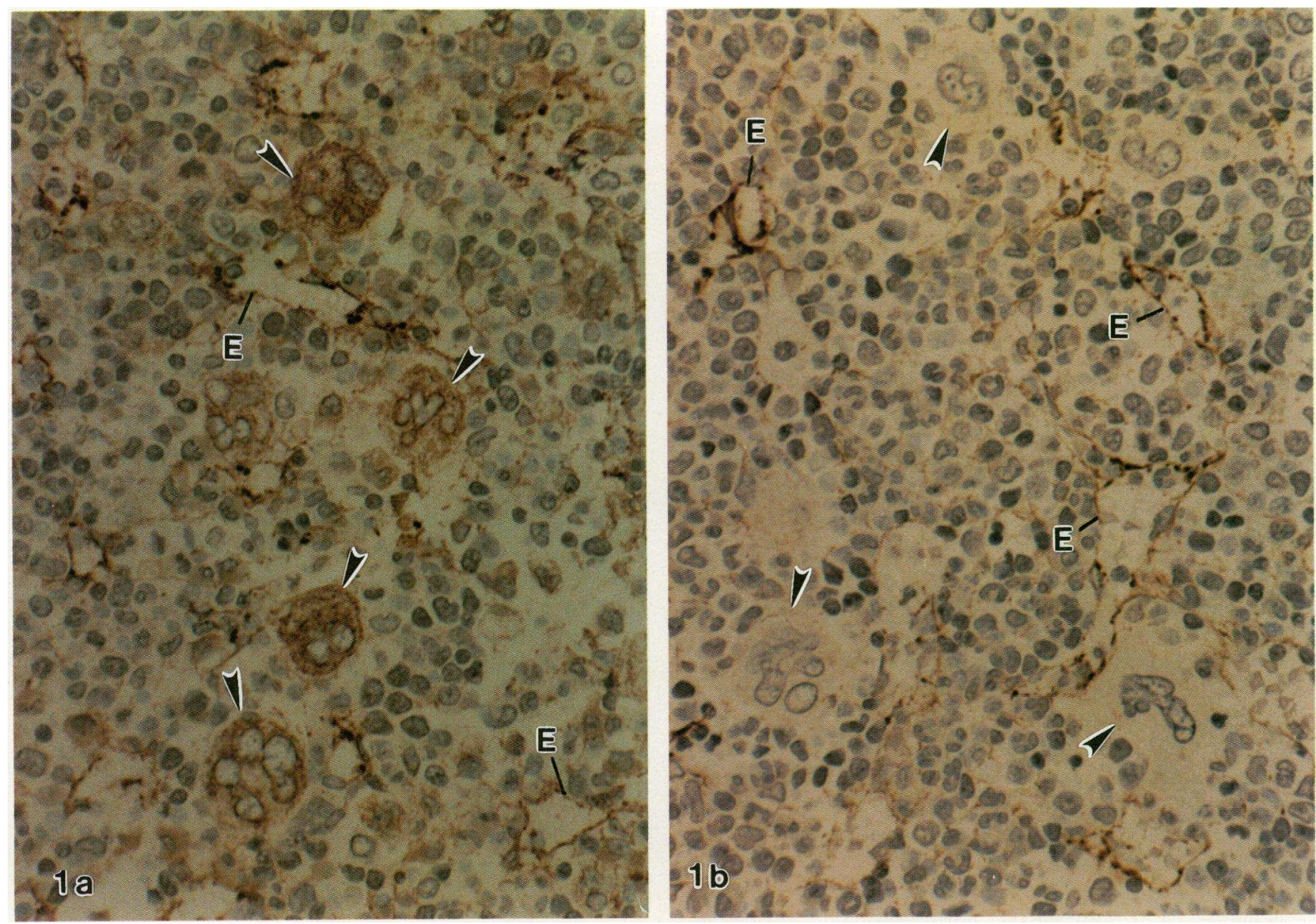

Figure 1. Light photomicrographs of perfusion fixed guinea pig bone marrow embedded in plastic and stained for the localization of biotinylated fibrinogen using streptavidin-horseradish peroxidase. The brown peroxidase reaction product is localized at antigenic sites. The tissue is counterstained with hematoxylin. (a) Bone marrow from a guinea pig killed $24 \mathrm{~h}$ after a bolus injection of biotinylated fibrinogen. The injected fibrinogen can be seen in megakaryocytes (arrowhead). Sinus endothelial cells $(E)$ also stain owing to the presence of injected biotinylated fibrinogen in circulation. $\times 343$. (b) Bone marrow from a guinea pig $24 \mathrm{~h}$ after a bolus injection of biotinylated fibrinogen. The guinea pig received a continuous infusion of kistrin for the duration of the experiment. The megakaryocytes (arrowhead) do not contain the labeled fibrinogen. The staining of sinus endothelial cells $(E)$ indicate the presence of biotinylated fibrinogen in the circulation. $\times 343$.

soids of kistrin-treated animals contained labeled fibrinogen comparable to controls (Fig. $1 \mathrm{~b}$ ). This indicated that even though the fibrinogen was circulating and available to megakaryocytes and platelets it was not endocytosed. Staining of megakaryocytes for two other $\alpha$-granule proteins, vWf and PF-

Table I. Quantitation of Staining for the Presence or Absence of Biotinylated Fibrinogen in Guinea Pig Bone Marrow Megakaryocytes

\begin{tabular}{lrcr}
\hline & \multicolumn{3}{c}{$\begin{array}{c}\text { Percentage of megakaryocytes } \\
\text { showing staining }\end{array}$} \\
\cline { 2 - 4 } $\begin{array}{l}\text { Intravenous administration } \\
\text { of biotinylated fibrinogen }\end{array}$ & None & Faint & Heavy \\
\hline With kistrin & 60 & 40 & 0 \\
With saline & 2 & 25 & 73
\end{tabular}

Values are given as percentages of total recognizable megakaryocytes in marrow. Values were derived from analysis of 200 megakaryocyte profiles under oil immersion.
4, which are synthesized endogenously, showed no difference between treated and control animals (not illustrated).

Controls. When bone marrow sections were preincubated with biotin-blocking reagents, no staining was seen with streptavidin-peroxidase, confirming the specificity of staining. Furthermore, bone marrow from untreated guinea pigs showed no staining. Substituting nonimmune serum for the primary antibody resulted in absence of all staining (not illustrated).

Localization of kistrin in megakaryocytes. When bone marrow from animals given biotinylated kistrin were stained with streptavidin-horseradish peroxidase, the labeled protein could be observed within megakaryocytes (not illustrated).

\section{Studies on platelets}

Platelet aggregation. Kistrin inhibited collagen-induced aggregation of guinea pig platelets in vitro in a dose-dependent manner. Even at concentrations as low as $50 \mathrm{nM}$, kistrin was able to completely inhibit platelet aggregation in guinea pig whole blood (data not shown). Similarly, platelet aggregation was completely inhibited in animals receiving kistrin infusions (Fig. 2). The petechial and ecchymotic hemorrhages observed 


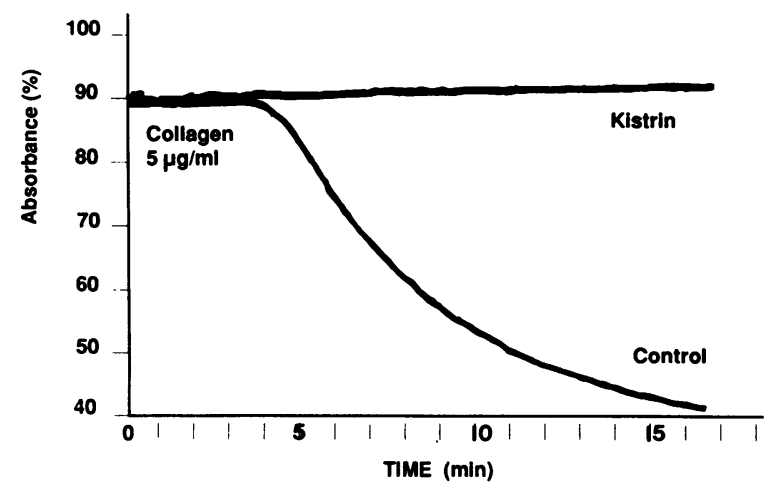

Figure 2. Inhibition of collagen-induced platelet aggregation in whole blood by the infusion of kistrin into a guinea pig. The platelets obtained from the control animal, which was given a saline infusion, aggregated rapidly in response to $5 \mu \mathrm{g} / \mathrm{ml}$ collagen, whereas blood obtained after $25 \mathrm{~h}$ of kistrin infusion $(200 \mu \mathrm{g} / \mathrm{h})$ showed no aggregation.

on skin and internal organs during necropsy of these animals were consistent with kistrin-induced platelet dysfunction. These findings indicate that kistrin binds to the fibrinogen receptor on guinea pig platelets and inhibits fibrinogen binding at concentrations comparable to human platelets.

Platelet counts. No significant difference in platelet counts was observed between treated and control animals. In kistrintreated as well as in control animals, platelet counts remained between 484 and $694 \times 10^{3} / \mu$ l, which is within the reported normal range for the guinea pig (18).

Effect of kistrin on incorporation of fibrinogen into platelets. As shown in fig. 3 (left), labeled fibrinogen could not be detected in platelets of kistrin-treated animals. The technique used to detect biotinylated fibrinogen in platelets was extremely sensitive (Fig. 3, right): $<5 \mathrm{ng}$ of labeled fibrinogen

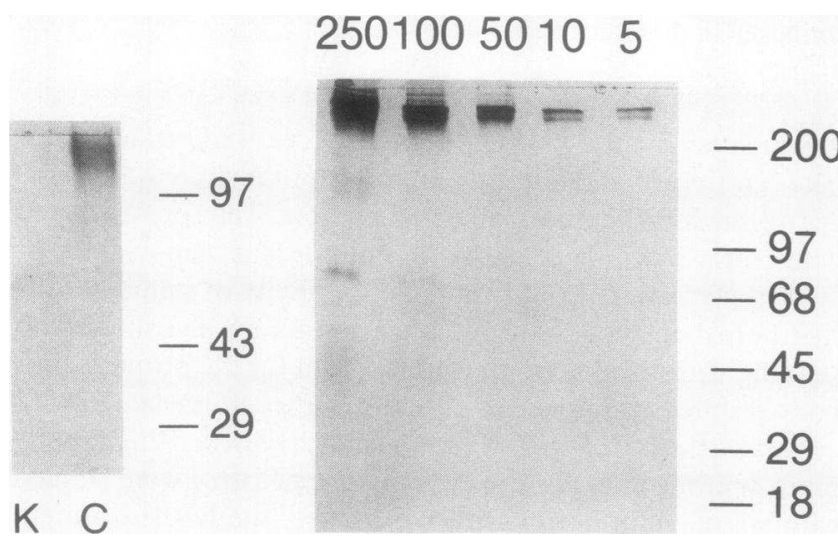

Figure 3. Inhibition of fibrinogen endocytosis by kistrin. (Left) Biotinylated fibrinogen was injected into guinea pigs with $(K)$ or without (C) $5 \mathrm{mg}$ of kistrin. Blood was collected at $24 \mathrm{~h}$ and platelets were purified and subjected to Western blotting using avidin-horseradish peroxidase. Lane 1 , platelets $\left(2 \times 10^{7}\right)$ from a kistrin-treated animal; lane 2, platelets $\left(2 \times 10^{7}\right)$ from control animal. (Right) Detection of known amounts of biotinylated fibrinogen by Western blotting. A dilution series of 5-250 ng of biotinylated fibrinogen was electrophoresed in an unreduced SDS-5\% polyacrylamide gel, transferred to nitrocellulose, and blotted with avidin horseradish peroxidase. could be demonstrated. Using the semiquantitative Western assay, we estimated that in control animals $\sim 50 \mathrm{ng}$ of the injected biotinylated fibrinogen per $2 \times 10^{7}$ platelets was present $24 \mathrm{~h}$ after infusion. In that the lower detection threshold is 5 ng, kistrin-treated animals had $<5 \mathrm{ng}$ of biotinylated fibrinogen in $2 \times 10^{7}$ of their platelets. This shows that platelets from treated animals contained $<10 \%$ of the biotinylated fibrinogen estimated to be present in control platelets.

Effect of Kistrin on other $\alpha$-granule proteins. We next determined whether blockage of $\alpha_{\mathrm{IIb}} \beta_{3}$ by kistrin affected endogenous $\alpha$-granule proteins. Platelets from control and kistrintreated animals were analyzed by Western immunoblotting for PF-4 (Fig. 4, left) and the reduced $\left(M_{\mathrm{r}} \simeq 220,000\right)$ subunit of vWf (Fig. 4, right). There was no detectable difference in these two endogenously synthesized proteins in controls and in animals infused with kistrin. The fact that kistrin did not alter two $\alpha$-granule proteins known to be synthesized by megakaryocytes but completely inhibited the appearance of biotinylated fibrinogen in platelets suggests that this effect is due primarily to uptake of the latter and not to a generalized alteration of $\alpha$ granule proteins. Furthermore, the platelet albumin level in a guinea pig receiving kistrin was $10.1 \mathrm{fg}$ per platelet, whereas that of a control animal receiving saline was $9.2 \mathrm{fg}$ per platelet. Human platelets which are slightly larger than those in the guinea pig contain $14.5 \pm 4.1 \mathrm{fg}$ per platelet (19). Thus, albumin an $\alpha$-granule protein derived exclusively from endocytosis also appears to be unchanged by the Kistrin infusion.

Although endogenous vWf is likely to represent most or all of that found in platelets, it is possible that a minor fraction of $\alpha$-granule vWf is endocytosed from plasma via $\alpha_{\mathrm{IIb}} \beta_{3}$ because it binds to this receptor (20) as well as to glycoprotein Ib (21).

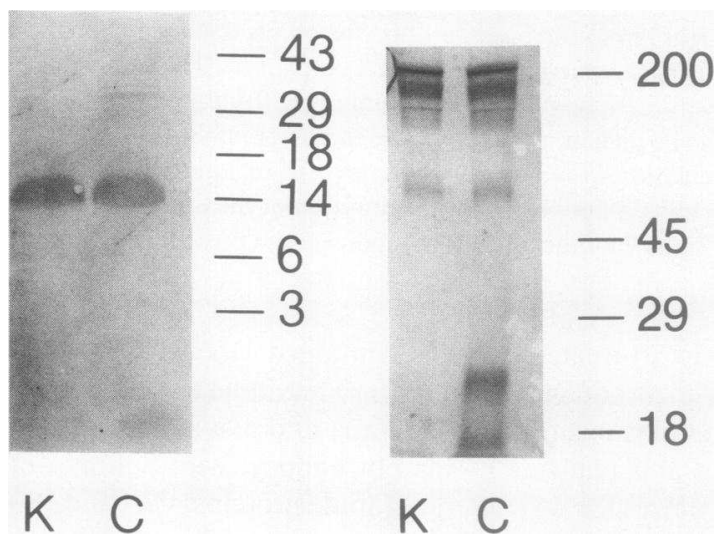

Figure 4. Platelet $\alpha$-granule proteins in kistrin-treated guinea pigs. Platelets purified from control $(C)$ or kistrin-treated animals $(K)$ were subjected to Western blotting using antibodies against PF-4 (left) or $\mathrm{vWf}\left(\right.$ right). (Left) $2 \times 10^{7}$ platelets were electrophoresed in unreduced gels containing $18 \%$ polyacrylamide-SDS at $100 \mathrm{~V}$ and transferred at $100 \mathrm{~V}$ for $1 \mathrm{~h}$ to $0.1-\mathrm{mm}$ nitrocellulose. Rabbit anti-human PF-4, diluted 1:100 in $1 \%$ gelatin was incubated with the filter for $1 \mathrm{~h}$ at room temperature $\left(\sim 20^{\circ} \mathrm{C}\right)$, washed, incubated with goat anti-rabbit IgG conjugated to biotin 1:500 for $1 \mathrm{~h}$, washed, then incubated with avidin-horseradish peroxidase (1:500) for $30 \mathrm{~min}$, and washed. The reaction was terminated with 4 chloronapthol $+\mathrm{H}_{2} \mathrm{O}_{2}$. (Right) 2 $\times 10^{7}$ platelets were electrophoresed in reduced gels containing $5 \%$ polyacrylamide-SDS at $100 \mathrm{~V}$ for $1 \mathrm{~h}$, transferred at $100 \mathrm{~V}$ for $1 \mathrm{~h}$ to $0.45-\mathrm{mm}$ nitrocellulose, then incubated with rabbit anti-human $v W f$ antibody diluted $1: 500$ in $1 \%$ gelatin for $1 \mathrm{~h}$. The remainder of the procedure was as described for the left panel. 
Western blotting is not sufficiently quantitative to exclude the possibility that kistrin inhibited the uptake of circulating $\mathrm{vWf}$ if it constituted a relatively small fraction of the total $\alpha$-granule protein. An immunoreactive band, $M_{\mathrm{r}} \approx 24,000$, was seen in control but not in kistrin-treated animals (Fig. 4b). The significance of this band and its absence in platelets from animals treated with kistrin is unclear.

Electronmicroscopic localization of kistrin in platelets. To determine if the kistrin that bound to the platelet endocytic receptor was internalized and incorporated into $\alpha$-granules, we performed ultrastructural localization of kistrin on platelets collected after $4 \mathrm{~h}$ of infusion. In that an antibody against kistrin was not available to us, we labeled the kistrin with biotin and localized the biotinylated protein in platelets. Platelets contained endocytosed kistrin within $\alpha$-granules and other organelles (Fig. 5). There was marked variability in the amount and location of kistrin among platelets. Some platelets had only an occasional $\alpha$-granule that contained kistrin (Fig. $5 a$ ). Frequently, labeling was closely associated with the granule membrane (Fig. $5 a$ ). Labeling was also seen on the platelet plasma membrane (Fig. 5, $b$ and $d$ inset). Kistrin was sometimes observed within organelles other than typical $\alpha$-granules (Fig. 5, $b$ and $c$ ). Multiple kistrin-containing $\alpha$-granules were seen in $\sim 15 \%$ of the platelets (Fig. 5). Only about $60 \%$ of platelets labeled for the presence of kistrin. Because the lifespan of a guinea pig platelet appears to be about $4 \mathrm{~d}$, only a small percentage of platelets would be shed from bone marrow megakaryocytes during the 4-h period of kistrin infusion. Thus, it is likely that at least some of the kistrin was endocytosed by circulating platelets.

\section{Discussion}

Endocytosis of biotinylated fibrinogen by megakaryocytes and platelets was prevented by the intravenous infusion of kistrin, an RGD-containing protein that inhibits fibrinogen binding to integrins. The mechanism of inhibition presumably is due to kistrin binding in vivo to megakaryocyte and platelet integrins that bind fibrinogen, preventing delivery of fibrinogen to its storage site, the $\alpha$-granule. Indeed, we have been able to follow the relocation of biotinylated kistrin from its binding on the plasma membrane to the membranes surrounding $\alpha$-granules after internalization. Because fibrinogen, which is $10 \%$ of the protein of $\alpha$-granules $(22,23)$, is not synthesized by megakaryocytes (1-3) and is highly concentrated relative to its presence in plasma (7), we feel justified in concluding that it is delivered to its storage site by receptor-mediated endocytosis. Furthermore, it appears to be mediated by integrins, because endocytosis can be prevented by an integrin antagonist. Our data are in accord with observations that platelet-fibrinogen levels decrease in humans (24) and monkeys (25) after the infusion of antibodies against $\alpha_{\mathrm{IIb}} \beta_{3}$.

In most cell types, proteins contained in secretory granules are endogenously synthesized and then packaged into granules (26). In addition to endogenous proteins, a few cell types such as basophilic leukocytes (27), mast cells, granule-containing lymphocytes (28), salivary gland cells (29), and megakaryocytes (30) also incorporate exogenous proteins into their granules by endocytosis; however, little is known about the mechanisms and pathways involved in the uptake and incorporation of these exogenous proteins into granules. Coated pits and vesi- cles containing the tracer protein horseradish peroxidase, as well as fibrinogen attached to colloidal gold, have been reported in platelets and megakaryocytes $(30,31)$. Recently, it was shown that coated pit-mediated internalization of the LDL receptor requires the presence of the consensus sequence NP $X Y$ (where $X$ stands for any amino acid) in the cytoplasmic tail (32). It is interesting that the NPXY sequence is also found in cytoplasmic domains of some integrin subunits, including platelet GP IIIa (32). Although receptor-mediated endocytosis of many ligands is well characterized, their destination is usually the endosomal or lysosomal compartments (33-35). The fibrinogen endocytosed by megakaryocytes is incorporated into $\alpha$-granules and the platelets are able to secrete the intact fibrinogen molecule upon stimulation $(4,36)$. Thus, the integrin-mediated endocytosis of fibrinogen in megakaryocytes and platelets and its incorporation into a secretory granule may involve a previously unrecognized pathway. The present data show that even when a nonphysiologic protein such as kistrin binds to this receptor, it is targeted to the $\alpha$-granule.

Kistrin has been shown to bind $\alpha_{\mathrm{IIb}} \beta_{3}$ and inhibit fibrinogen binding (14). Kistrin may, however, also bind to the vitronectin receptor $\left(\alpha^{\mathrm{v}} \beta_{3}\right)$, another fibrinogen-binding platelet integrin (16). Thus, $\alpha_{\mathrm{IIb}} \beta_{3}, \alpha^{\mathrm{v}} \beta_{3}$ or both may mediate the endocytosis of fibrinogen into $\alpha$-granules. Several lines of evidence, however, suggest that $\alpha_{\mathrm{IIb}} \beta_{3}$ may be the primary receptor that mediates fibrinogen uptake, including (a) patients with Glanzmanns' thrombasthenia who congenitally lack $\alpha_{\mathrm{II}} \beta_{3}$ have a deficiency of platelet fibrinogen (37), which has also been reported in a group of thrombasthenics who lack $\alpha_{\mathrm{IIb}} \beta_{3}$ but who have normal or increased amounts of $\alpha^{\mathrm{v}} \beta_{3}$ (13); (b) fibrinogen $\gamma^{\prime}$ variant, which binds weakly to $\alpha_{\mathrm{II}} \beta_{3}$, is not found in platelet $\alpha$-granules even though it constitutes $10 \%$ of normal plasma fibrinogen (38); (c) the platelets of Paris I type dysfibrinogenemia patients do not contain abnormal fibrinogen, although $50 \%$ of the fibrinogen molecules in plasma have the defect (39). Binding of the abnormal Paris I fibrinogen to $\alpha_{\mathrm{IIb}} \beta_{3}$ is impaired (40); (d) compared to $\alpha_{\mathrm{IIb}} \beta_{3}\left(50,000\right.$ copies per platelet) the $\alpha^{\mathrm{v}} \beta_{3}$ (100 copies per platelet) is a relatively minor platelet integrin. These observations, when taken together with the present experimental data, strongly suggest that the primary receptor that mediates fibrinogen endocytosis is $\alpha_{\mathrm{IIb}} \beta_{3}$.

A variety of ligands, including fibrinogen, vWf, fibronectin, and thrombospondin, bind to $\alpha_{\mathrm{IIb}} \beta_{3}$ on stimulated platelets (41). The recognition sequence common to these proteins is RGD. The fibrinogen molecule contains two RGD sequences both on the A $\alpha$ chain and an additional $\alpha_{\mathrm{IIb}} \beta_{3}$ binding site located at the carboxyl-terminus of the $\gamma$ chain, which includes 12 amino acids, but does not contain the RGD sequence (42). This dodecapeptide and RGD containing peptides compete with each other for binding to $\alpha_{\mathrm{IIb}} \beta_{3}$ (43). Thus, kistrin may inhibit both dodecapeptide- and RGD- mediated fibrinogen binding to $\alpha_{\mathrm{IIb}} \beta_{3}$.

The ability of $\alpha_{\mathrm{II} b} \beta_{3}$ to function as an endocytic receptor on resting megakaryocytes and platelets may be questioned because it is well known that $\alpha_{\mathrm{IIb}} \beta_{3}$ on platelets binds soluble fibrinogen only after "activation" (44). The fact that $\alpha_{\mathrm{II}} \beta_{3}$ on unstimulated cells has the ability to interact with fibrinogen under certain conditions may provide a possible explanation. Thus, immobilized fibrinogen may bind to $\alpha_{\mathrm{IIb}} \beta_{3}$ without activation (45-47). This receptor function of $\alpha_{\mathrm{II}} \beta_{3}$ on unstimulated cells appears to differ from that of the activated state because it is selective for fibrinogen $(46,48)$. Recently it was 

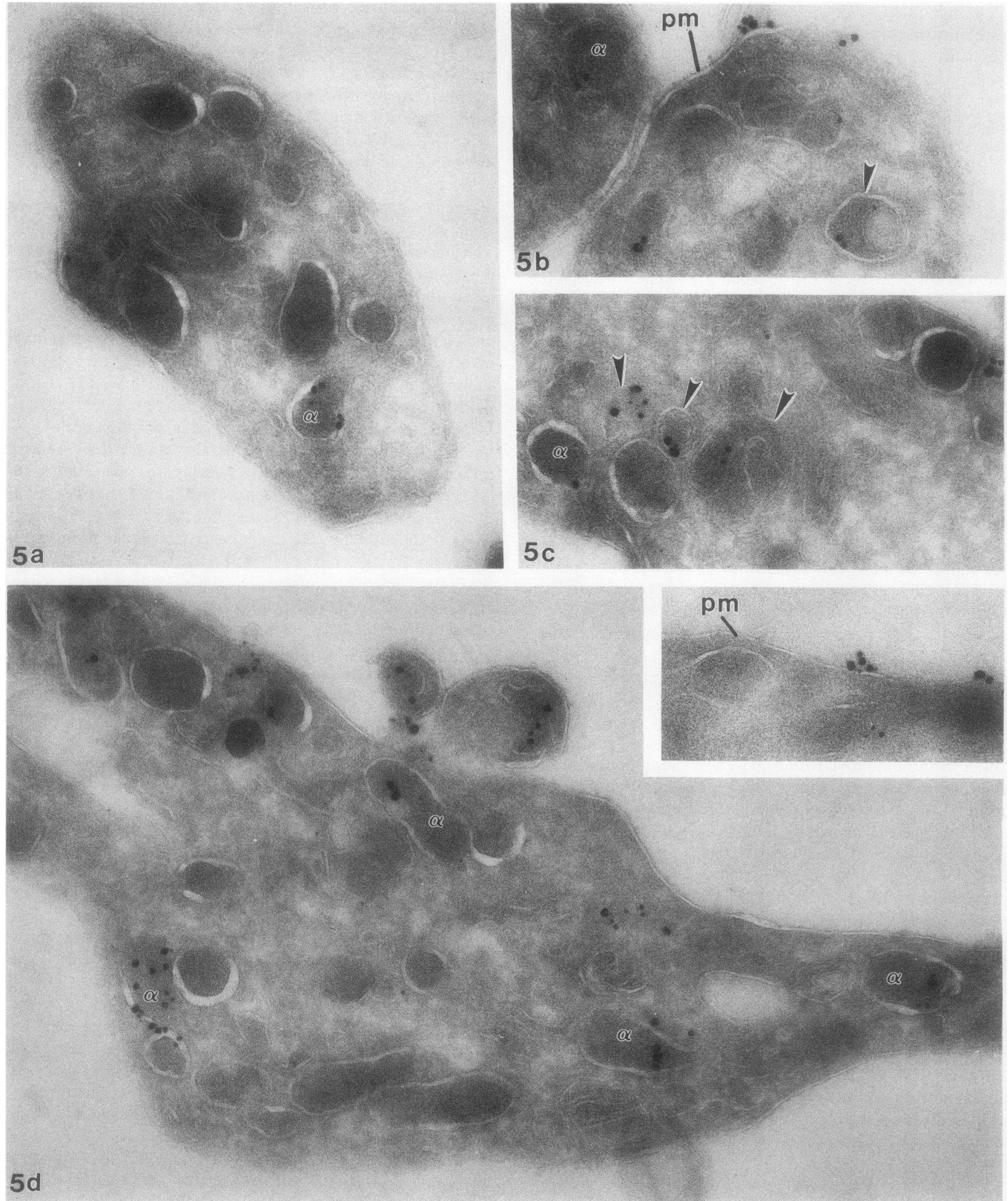

Figure 5. Transmission electron micrographs showing the localization of kistrin in platelets obtained from a guinea pig given biotinylated kistrin for $4 \mathrm{~h}$ in the form of a continuous infusion. Frozen thin sections of platelets were stained for labeled kistrin using an anti-biotin antibody and an immunogold label that was enhanced with silver. Considerable variability in amount and cellular location of label was seen among platelets. (a) A platelet with one $\alpha$-granule containing kistrin. Note the close association of the label with the $\alpha$-granule $(\alpha)$ membrane. ( $b$ and $c)$ Kistrin localized within platelet organelles other than typical $\alpha$-granules (arrowheads). Kistrin is also seen attached to the platelet plasma membrane $(\mathrm{pm}) .(\mathrm{d})$ platelet with several $\alpha$-granules containing kistrin. (Inset) Kistrin bound to platelet plasma membrane $(p m) . a \times 70,000 ; b \times 88,000 ; c$

$\times 74,000 ; d \times 74,000 ;$ inset $\times 82,000$ 
also shown that $\alpha_{\mathrm{IIb}} \beta_{3}$ on unstimulated cells can interact with fibrinogen bound to integrins on other cells (49). Thus, resting $\alpha_{\mathrm{II}} \beta_{3}$ on megakaryocytes and platelets may bind a fibrinogen molecule that is already bound to a different integrin (e.g., $\alpha^{\mathrm{v}} \beta_{3}$ ) on the same or a different cell. It is interesting that in addition to megakaryocytes and platelets, $\alpha^{\mathbf{v}} \beta_{3}$ is present on several cell types, including endothelial cells, macrophages, and smooth muscle cells, which are present in bone marrow stroma $(8,50-52)$. Activation is not required for fibrinogen binding to $\alpha^{\mathrm{v}} \beta_{3}$ because the receptor function is constitutive. Thus, it is possible that megakaryocytes and platelets have access to the fibrinogen that binds to the surface of cells and/or is contained in the extracellular matrix within the marrow compartment as well as to endothelial cells that are capable of binding fibrinogen to nonactivated $\alpha_{\mathrm{IIb}} \beta_{3}$.

Although the role of integrins in the cell adhesion is well documented, the present study describe integrins acting as receptors for protein trafficking to secretory granules. A somewhat similar function of integrins described recently involve the entry of certain microbial pathogens into host cells $(53,54)$. Some bacteria appear to utilize the $\beta 1$-integrin family of cell adhesion molecules as invasin receptors. Invasin, a 103-kD outer membrane protein, promotes invasion of mammalian cells by bacteria such as certain strains of Eschericia coli and Yersinia tuberculosis $(55,56)$. Specific binding of purified invasin to $\beta 1$ chain paired to $\alpha$ chains $3,4,5$, or 6 (57) suggests that attachment and entry into cells of bacteria expressing invasin requires these integrins. Other examples of integrin-mediated phagocytic uptake of microbes include Legionella pneumophilia (58), Bordetella pertussis (59), and the protozoan Leishmania (60).

There is little information on endocytosis and recycling of either occupied or free integrins. It has been shown that the fibronectin receptor expressed in $\mathrm{CHO}$ cells is constitutively endocytosed and recycles with a time course of 80 minutes $(61$, $62)$. The internalization of this integrin appears to be independent of receptor occupancy (62). The actual mechanisms involved in endocytosis of the fibronectin receptor, or its physiologic significance, however, have not been determined. Particularly relevant to the present study is the demonstration of an actively cycling pool of $\alpha_{\mathrm{IIb}} \beta_{3}$ in platelets $(63,64)$ and its presence on the $\alpha$-granule membrane $(65,66)$. However, the intragranular storage pattern determined by immunoelectron microscopy shows fibrinogen to be randomly distributed in the matrix of $\alpha$-granules except the nucleoid $(67,68)$. This suggests that at least some of the fibrinogen molecules within $\alpha$-granules may dissociate from their membrane-bound receptor. The endocytosed kistrin that was incorporated into $\alpha$-granules showed a similar distribution, suggesting that some of the kistrin molecules may have dissociated from their receptor/s after reaching the $\alpha$-granule.

The functional role of platelet integrins has been exclusively associated with their well-established cell-cell and cellmatrix interactions. Thus, the sole function attributed to integrins such as $\alpha_{\mathrm{IIb}} \beta_{3}$ is their role in platelet aggregation during formation of the hemostatic plug. This study draws attention to a previously unrecognized function of integrins that come into play during the development of cells of the platelet lineage, namely receptor-mediated endocytosis and storage of a major granule protein. It is possible that integrin-mediated endocytosis of exogenous proteins may in fact be a widely prevelant physiologic phenomenon that has not been previously recognized.

\section{Acknowledgments}

The authors acknowledge the editorial assistance of Merle Jolson and David Geller.

This work was supported by grants HL-31610 and HL-33277 from the National Heart, Lung, and Blood Institute of the National Institutes of Health.

\section{References}

1. Handagama, P., D. A. Rappolee, Z. Werb, J. Levin, and D. F. Bainton. 1990. Platelet alpha-granule fibrinogen, albumin and immunoglobulin $G$ are not synthesized by rat and mouse megakaryocytes. J. Clin. Invest. 86:1364-1368.

2. Lange, W., A. Luig, G. Dolken, R. Mertelsmann, and L. Kanz. 1991. Fibrinogen $\gamma$-chain mRNA is not detected in human megakaryocytes. Blood. 78:20-25.

3. Louache, F., N. Debili, E. Cramer, J. Breton-Gorius, and W. Vainchenker. 1991. Fibrinogen is not synthesized by human megakaryocytes. Blood. 77:311316.

4. Handagama, P. J., M. A. Shuman, and D. F. Bainton. 1989. Incorporation of intravenously injected albumin, immunoglobulin $\mathrm{G}$ and fibrinogen in guinea pig megakaryocyte granules. J. Clin. Invest. 84:73-82.

5. Harrison, P., B. R. Wilbourn, N. Debili, W. Vainchenker, J. Breton-Gorius, A. S. Lawrie, J. M. Masse, G. F. Savidge, and E. M. Cramer. 1989. Uptake of plasma fibrinogen into the $\alpha$-granules of human megakaryoctes and platelets. $J$. Clin. Invest. 84:1320-1324.

6. Harrison, P., G. F. Savidge, and E. M. Cramer. 1990. The origin and physiological relevance of $\alpha$-granule adhesive proteins. Br. J. Haematol. 74:125130.

7. George, J. N. 1990. Immunoglobulin G: its significance for the evaluation of thrombocytopenia and for understanding the origin of $\alpha$-granule protein. Blood. 76:859-870.

8. Hynes, R. O. 1987. Integrins: a family of cell surface receptors. Cell. 48:549-554.

9. Kieffer, N., and D. R. Phillips. 1990. Platelet membrane glycoproteins: functions in cellular interactions. Annu. Rev. Cell Biol. 6:329-357.

10. Ruoslahti, E. 1991. Integrins. J. Clin. Invest. 87:1-5.

11. Cheresh, D. A. 1987. Human endothelial cells synthesize and express an Arg-Gly-Asp-directed adhesion receptor involved in attachment to fibrinogen and von Willebrand factor. Proc. Natl. Acad. Sci. USA. 84:6471-6475.

12. Charo, I. F., Beckeart, L. S., and Phillips, D. R. 1987. Platelet glycoprotein IIb-IIIa-like proteins mediate endothelial cell attachment to adhesive proteins and the extracellular matrix. J. Biol. Chem. 262:9935-9938.

13. Coller, B. S., U. Seligsohn, S. M. West, L. E. Scudder, and K. J. Norton. 1991. Platelet fibrinogen and vitronectin in Glanzmann thrombasthenia: evidence consistent with specific roles for glycoprotein IIb/IIIa and $\alpha^{\mathrm{v}} \beta_{3}$ Integrins in platelet protein trafficking. Blood. 78:2603-2610.

14. Dennis, M. S., W. J. Henzel, R. M. Pitti, M. T. Lipari, M. A. Napier, T. A. Deisher, S. Bunting, and R. A. Lazarus. 1989. Platelet glycoprotein Ilb-IIla protein antagonists from snake venoms: evidence for a family of platelet-aggregation inhibitors. Proc. Natl. Acad. Sci. USA. 87:2471-2475.

15. Gould, R. J., M. A. Polokoff, P. A. Friedman, T.-F. Huang, J. C. Holt, J. J. Cook, and S. Niewiarowski. 1990. Disintegrins: a family of integrin inhibitory proteins from viper venoms ${ }_{(431298)}$ Proc. Soc. Exp. Bio. Med. 195:168-171.

16. Scarborough, R. M., J. W. Rose, M. A. Hsu, D. R. Phillips, V. A. Fried A. M. Campbell, L. Nannizzi, and I. F. Charo. 1991. Barbourin, a GPIIb-IIla-specific integrin antagonist from the venom of Sistrurus $m$. barbouri. J. Biol. Chem. 266:9359-9362.

17. Stierhof, Y.-D., B. M. Humbel, and H. Schwarz. 1991. Suitability of different silver enhancement methods applied to $1 \mathrm{~nm}$ colloidal gold particles: an immunoelectron microscopic study. J. Electron Microsc. Tech. 17:336-343.

18. Jain, N. C. 1986. Normal values in blood of laboratory, fur bearing, and miscellaneous zoo, domestic, and wild animals. In Schalm's Veterinary Hematology, 4th edition. N.C. Jain, editor. Lea \& Febiger, Philadelphia. 274-349.

19. George, J. N., S. Saucerman, S. P. Levine, and L. K. Knieriem. 1985. Immunoglobulin $\mathrm{G}$ is a platelet alpha granule-secreted protein. J. Clin. Invest. 76:2020-2025.

20. Ruggeri, Z. M., R. Bader, and L. D. Marco. 1982. Glanzmann thrombasthenia: deficient binding of von Willebrand factor to thrombin-stimulated platelets. Proc. Natl. Acad. Sci. USA. 79:6038-6041.

21. Coller, B. S., E. I. Peerschke, L. E. Scudder, and C. A. Sullivan. 1983. Studies with a murine monoclonal antibody that abolishes ristocetin-induced 
binding of von Willebrand factor to platelets: additional evidence in support of GP Ib as a platelet receptor for von Willebrand factor. Blood. 61:99-110.

22. Bezkorovainy, A., and M. A. Rafelson. 1964. Characterization of some proteins from normal human platelets. J. Lab. Clin. Med. 64:212-225.

23. Nachman, R. L., A. J. Marcus, and D. Zucker-Franklin. 1967. Immunologic studies of proteins associated with subcellular fractions of normal human platelets. J. Lab. Clin. Med. 69:651-658.

24. Harrison, P., E. M. Cramer, B. R. Wilbourn, R. Faint, I. Mackie, S. Bhattacharya, N. Saito, A. Lahiri, R. Jordan, S. J. Machin, et al. 1990. The influence of therapeutic blockage of GP IIb-IIIa on platelet $\alpha$-granule fibrinogen. Blood. 76:458a. (Abstr.)

25. Suzuki, M., T. Kawakatsu, H. Nagata, K. Hamamoto, K. Iwata, S. Ohga, S. Nomura, T. Kokawa, and K. Yasunaga. 1992. Effect of injected antibody against the platelet glycoprotein IIb-IIla complex on monkey platelet fibrinogen. Thromb. Haemostasis. 67:578-581.

26. Palade, G. 1975. Intracellular aspects of the process of protein synthesis. Science (Wash. DC). 189:347-358.

27. Dvorak, A. M., H. F. Dvorak, and M. J. Karnovsky. 1972. Uptake of horseradish peroxidase by guinea pig basophilic leukocytes. Lab. Invest. 26:2739.

28. Dvorak, A. M., S. J. Klebanoff, W. F. Henderson, R. A. Monahan, K. Pyne, and S. J. Galli. 1985. Vesicular uptake of eosinophil peroxidase by guinea pig basophils and cloned mouse mast cells and granule-containing lymphoid cells. Am. J. Pathol. 118:425-438.

29. Oliver, C., and A. R. Hand. 1978. Uptake and fate of luminally administered horseradish peroxidase in resting and isoproterenol-stimulated rat parotid acinar cells. J. Cell Biol. 76:207-220.

30. Handagama, P. J., J. N. George, M. A. Shuman, R. P. McEver, and D. F. Bainton. 1987. Incorporation of a circulating protein into megakaryocyte and platelet granules. Proc. Natl. Acad. Sci. USA. 84:861-865.

31. Behnke, O. 1989. Coated pits and vesicles transfer plasma components to platelet granules. Thromb. Haemostasis. 62:718-722.

32. Chen, W.-J., J. L. Goldstein, and M. S. Brown. 1990. NPXY, a sequence often found in cytoplasmic tails, is required for coated pit-mediated internalization of the low density lipoprotein receptor. J. Biol. Chem. 265:3116-3123.

33. Gruenberg, J., and K. E. Howell. 1989. Membrane traffic in endocytosis:insights from cell-free assays. Annu. Rev. Cell Biol. 5:453-481.

34. Hubbard, A. L. 1989. Endocytosis. Curr. Opin. Cell Biol. 1:675-683.

35. Kornfeld, S., and I. Mellman. 1989. The biogenesis of lysosomes. Annu. Rev. Cell Biol. 5:483-525.

36. Handagama, P. J., M. A. Shuman, and D. F. Bainton. 1990. The origin of platelet alpha granule proteins. In Molecular Biology and Differentiation of Megakaryocytes. J. Breton-Gorius, A. T. Nurden, J. Levin, and N. Williams, editors. Wiley-Liss, New York. 119-130.

37. George, J. N., J. P. Caen, and A. T. Nurden. 1990. Glanzmann's thrombasthenia: the spectrum of clinical disease. Blood. 75:1383-1395.

38. Kunicki, T. J., P. J. Newman, D. L. Amrani, and M. W. Mosesson. 1985. Human platelet fibrinogen: purification and hemostatic properties. Blood 66:808-815.

39. Jandrot-Perrus, M., M. W. Mosesson, M.-H. Denninger, and D. Menache 1979. Studies of platelet fibrinogen from a subject with a congenital plasma fibrinogen abnormality (fibrinogen Paris I). Blood. 54:1109-1116.

40. Denninger, M.-H., M. Jandrot-Perrus, O. Elion, O. Bertrand, G. A. Homandberg, M. W. Mosesson, and M.-C. Guillin. 1987. ADP-induced platelet aggregation depends on the conformation or availability of the terminal gamma chain sequence of fibrinogen: study of the reactivity of fibrinogen Paris I. Blood. 70:558-563.

41. Plow, E. F., and M. H. Ginsberg. 1988. Cellular adhesion: GP IIb-IIIa as a prototypic adhesion receptor. Prog. Hemostasis Thromb. 9:117-156.

42. Kloczewiak, M., S. Timmons, T. J. Lukas, and J. Hawiger. 1984. Platelet receptor recognition site on human fibrinogen, synthesis and structure-function relationship of peptides corresponding to the carboxyterminal segment of the $\gamma$ chain. Biochemistry. 23:1767-1774.

43. Lam, S. C.-T., E. F. Plow, M. A. Smith, A. Andrieux, J.-J. Ryckwaert, G. Marguerie, and M. H. Ginsberg. 1987. Evidence that arginyl-glycyl-aspartate peptides and fibrinogen $\gamma$ chain peptides share a common binding site on platelets. J. Biol. Chem. 262:947-950.

44. Phillips, D. R., I. F. Charo, L. V. Parise, and L. A. Fitzgerald. 1988. The platelet membrane glycoprotein IIb-IIla complex. Blood. 71:831-843.

45. Coller, B. S. 1980. Interaction of normal, thrombasthenic, and Bernard Soulier platelets with immobilized fibrinogen: defective platelet-fibrinogen interaction in thrombasthenia. Blood. 55:169-178.
46. Kieffer, N., L. A. Fitzgerald, D. Wolf, D. A. Cheresh, and D. R. Phillips. 1991. Adhesive properties of the $\beta_{3}$ integrins: comparison of GP IIb-IIIa and the vitronectin receptor individually expressed in human melanoma cells. J. Cell Biol. 113:451-461.

47. Linden, I. N., G. McManama, L. Kushner, E. W. Merrill, and E. W. Salzman. 1986. Does the conformation of adsorbed fibrinogen dictate platelet interactions with artificial surfaces? Blood. 68:355-362.

48. Savage, B., and Z. M. Ruggeri. 1991. Selective recognition of adhesive sites in surface-bound fibrinogen by glycoprotein IIb-IIIa on nonactivated platelets. $J$. Biol. Chem. 266:11227-11233.

49. Gawaz, M. P., J. C. Loftus, M. L. Bajt, M. M. Frojmovic, E. F. Plow, and M. H. Ginsberg. 1991. Ligand bridging mediates integrin $\alpha_{\mathrm{IIb}} \beta_{3}$ (platelet GPIIbIIla) dependent homotypic and heterotypic cell-cell interactions. J. Clin. Invest. 88:1128-1134

50. Cheresh, D. A. 1987. Human endothelial cells synthesize and express an arg-gly-asp-directed adhesion receptor involved in attachment of fibrinogen and von Willebrand factor. Proc. Natl. Acad. Sci. USA. 84:6471-6475.

51. Ginsberg, M. H., J. C. Loftus, J.-J. Ryckwaert, M. D. Pierschbacher, R. Pytela, E. Ruoslahti, and E. F. Plow. 1987. Immunochemical and amino-terminal sequence comparison of two cytoadhesins indicates they contain similar or identical beta subunits and distinct alpha subunits. J. Biol. Chem. 262:54375440.

52. Krissansen, G. W., M. J. Elliott, C. M. Lucas, F. C. Stomski, M. C. Berndt D. A. Cheresh, A. F. Lopez, and G. F. Burns. 1990. Identification of a novel integrin $\beta$ subunit expressed on cultured monocytes (macrophages). J. Biol. Chem. 265:823-830.

53. Isberg, R. R. 1991. Discrimination between intracellular uptake and surface adhesion of bacterial pathogens. Science (Wash. DC). 252:934-938.

54. Falkow, S. 1991. Bacterial entry into eukaryotic cells. Cell. 65:1099-1102.

55. Isberg, R. R., D. L. Voohis, and S. Falkow. 1987. Identification of invasin: a protein that allows enteric bacteria to penetrate cultured mammalian cells. Cell. 50:769-778.

56. Isberg, R. R., and J. L. Leong. 1988. Cultured mammalian cells attach to the invasin protein of Yersinia pseudotuberculosis. Proc. Natl. Acad. Sci. USA. $85: 6682-6686$

57. Isberg, R. R., and J. M. Long. 1990. Multiple $\beta 1$ chain integrins are receptors for invasin, a protein that promotes bacterial penetration into mammalian cells. Cell. 60:861-871.

58. Payne, N. R., and M. A. Horwitz. 1987. Phagocytosis of Legionella pneumophilia is mediated by human monocyte complement receptors. J. Exp. Med. 166:1341-1348.

59. Relman, D., E. Tuomanen, S. Falkow, D. T. Golenbock, K. Saukonen, and S. D. Wright. 1990. Recognition of a bacterial adhesin by an integrin: macrophage CR3 (aMb2, CD1 1b/CD18) binds filamentous hemagglutinin of Bordetella pertussis. Cell. 61:1375-1382.

60. Russell, D. G., and S. D. Wright. 1988. Complement receptor type 3 (CR3) binds to an Arg-Gly-Asp-containing region of the major surface glycoprotein, gp63, of Leishmania promastigotes. J. Exp. Med. 168:279-292.

61. Bretscher, M. S. 1989. Endocytosis and recycling of the fibronectin receptor in CHO cells. EMBO (Eur. Mol. Biol. Organ.). 8:1341-1348.

62. Sczekan, M. M., and R. L. Juliano. 1990. Internalization of the fibronectin receptor is a constitutive process. $J$. Cell Physiol. 142:574-580.

63. Wencel-Drake, J. D. 1990. Plasma membrane GPIIb-IIIa: Evidence for a cycling receptor pool. Am. J. Pathol. 136:61-70.

64. Morgenstern, E., A. Ruf, and H. Patscheke. 1992. Transport of anti-glycoprotein IIb/IIIa-antibodies into the alpha-granules of unstimulated human blood platelets. Thromb. Haemostasis. 67:121-125.

65. Wencel-Drake, J. D., E. F. Plow, T. J. Kuniki, V. L. Woods, D. M. Keller, and M. H. Ginsberg. 1986. Localization of internal pools of membrane glycoproteins involved in platelet adhesive responses. Am. J. Pathol. 124:324-334.

66. Cramer, E. M., G. F. Savidge, W. Vainchenker, M. C. Berndt, D. Pidard, J. P. Caen, J.-M. Masse, and J. Breton-Gorius. 1990. Alpha-granule pool of glycoprotein IIb-IIIa in normal and pathologic platelets and megakaryocytes. Blood. 75:1220-1227.

67. Sander, H. J., J. W. Slot, B. N. Bouma, P. A. Bolhuis, D. S. Pepper, and J. J. Sixma. 1983. Immunocytochemical localization of fibrinogen, platelet factor 4 , and beta thromboglobulin in thin frozen sections of human blood platelets. $J$. Clin. Invest. 72:1277-1287.

68. Cramer, E. M., N. Debili, J. F. Martin, A.-M. Gladwin, J. Breton-Gorius, P. Harrison, G. F. Savidge, and W. Vainchenker. 1989. Uncoordinated expression of fibrinogen compared with thrombospondin and von Willebrand factor in maturing human megakaryocytes. Blood. 73:1123-1129. 